\title{
Transferrin receptors in human tissues: their distribution and possible clinical relevance
}

\author{
KEVIN C GATTER*, GEOFFREY BROWN $\dagger$, IAN S TROWBRIDGE $\ddagger$, RITA-ELIZABETH \\ WOOLSTON*, DAVID Y MASON* \\ From the *Nuffield Department of Pathology, University of Oxford, John Radcliffe Hospital, Oxford, the \\ †Department of Immunology, University of Birmingham Medical School, Edgbaston, Birmingham, and the \\ $\ddagger$ Department of Cancer Biology, the Salk Institute for Biological Studies, Post Office Box 85300, San Diego, \\ California, USA
}

SUMMARY The distribution of transferrin receptors (TR) has been studied in a range of normal and malignant tissues using four monoclonal antibodies, BK19.9, B3/25, T56/14 and T58/1. In normal tissues TR was found in a limited number of sites, notably basal epidermis, the endocrine pancreas, hepatocytes, Kupffer cells, testis and pituitary. This restricted pattern of distribution may be relevant to the characteristic pattern of iron deposition in primary haemachromatosis. In contrast to this limited pattern of expression in normal tissue, the receptor was widely distributed in carcinomas, sarcomas and in samples from cases of Hodgkin's disease. This malignancyassociated expression of the receptor may play a role in the anaemia of advanced malignancy by competing with the bone marrow for serum iron.

The majority of human cells absorb serum iron during their development. This requirement for iron varies considerably; in cells such as developing marrow normoblasts and placental syncytiotrophoblasts iron is required in large amounts for incorporation into haemoglobin or for transport to the developing fetus. In other cells iron is needed in smaller amounts but is nevertheless essential to normal development.

The first step in cellular iron uptake is binding of transferrin:iron complexes to the cell surface membrane. This appears to be mediated by a specific molecule known as the transferrin receptor (TR). There has recently been considerable interest in this molecule which appears to be expressed in much larger amounts on proliferating cells (compared to cells in the resting state) and on cells which have undergone malignant transformation. ${ }^{1-4}$ Furthermore TR is similar in several respects to the malignancy-associated glycoprotein reported by Bramwell and Harris. ${ }^{5}$ The latter molecule is expressed in substantially greater amounts on malignant than on non-malignant cells and is similar to TR in its molecular weight, its disulphide-bonded dimeric structure, its acidic nature, and its pattern of binding to lectins (concavalin $\mathrm{A}$ and wheat germ aggluti$\operatorname{nin}) .^{3}$

Accepted for publication 4 January 1983
Despite these interesting characteristics of the human transferrin receptor there have been no reports of its pattern of tissue distribution in normal and malignant tissue. Previous studies have been largely concerned with TR expression on in vitro human cell lines (Table 1). In the present study we have used four monoclonal antibodies specific for TR to visualise directly the molecule in sections of human tissue. This has revealed a striking distribution pattern in normal tissues, with selective expression in those sites which are most susceptible to excessive iron deposition in primary haemachromatosis-for example, skin, testis, pancreas, liver. Furthermore in a variety of different types of human malignancy it is possible to demonstrate strong immunohistological labelling for TR. This latter observation may be relevant to the development of low serum transferrin concentrations and unexplained anaemia in cases of advanced malignant disease.

\section{Material and methods}

PREPARATION OF TISSUE SAMPLES

Fresh samples of normal and malignant tissues were obtained from surgical operation specimens. Samples of placental tissue were obtained immediately after delivery. All samples were immediately frozen in liquid nitrogen and stored in a liquid nitrogen 
Table 1 Expression of transferrin receptor on human cells

\begin{tabular}{|c|c|c|}
\hline Author(s) & Method of Detection & Results \\
\hline Larrick, Gresswell (1979)' & $\begin{array}{l}\text { Binding of }{ }^{125} \text { I-labelled transferrin to human } \\
\text { cell lines }\end{array}$ & $\begin{array}{l}\text { TR present on human B and T } \\
\text { lymphoblastoid cell lines }\end{array}$ \\
\hline $\left.\begin{array}{l}\text { Seligman, Schleicher, Allen }(1979)^{7} \\
\text { Wada, Hass, Sussman }(1979)^{8} \\
\text { Faulk, Hsi, Stevens }(1980)^{9}\end{array}\right\}$ & $\begin{array}{l}\text { Binding of }{ }^{125} \text { I-labelled transferrin on } \\
\text { placental membranes } \\
\text { Immunofluorescence of tissue sections using } \\
\text { polyclonal rabbit anti-transferrin antibody }\end{array}$ & $\begin{array}{l}\text { TR present on human placental brush border } \\
\text { membrane (syncytiotrophoblast) } \\
\text { Normal breast negative }(100 \%) \text { Carcinoma } \\
\text { of breast positive }(72 \%)\end{array}$ \\
\hline $\begin{array}{l}\text { Enns, Shindelman, Tonik, } \\
\text { Sussman }(1981)^{10}\end{array}$ & $\begin{array}{l}\text { Binding of }{ }^{125} \text { I-labelled transferrin to human } \\
\text { cell lines }\end{array}$ & $\begin{array}{l}\text { TR present on placental syncytiotrophoblast, } \\
\text { on choriocarcinoma cell line but absent from } \\
\text { normal breast cells }\end{array}$ \\
\hline Goding, Burns (1981) & $\begin{array}{l}\text { Precipitation of TR with monoclonal } \\
\text { OKT9-detection by two dimensional } \\
\text { electrophoresis }\end{array}$ & $\begin{array}{l}\text { TR present on human } T \text { cell leukaemia line } \\
\text { CCRF-CEM }\end{array}$ \\
\hline Sutherland et al. $(1981)^{3}$ & $\begin{array}{l}\text { Binding of monoclonal antibody OKT9 with } \\
\text { a variety of human cell lines; assessment by } \\
125 \text { I-labelled anti-mouse Ig binding or by } \\
\text { indirect immunofluorescence }\end{array}$ & $\begin{array}{l}\text { TR present on numerous human leukaemia } \\
\text { cell lines and on several carcinoma cell lines } \\
\text { (pancreas, melanoma, bladder, rectum, oat } \\
\text { cell, teratoma) }\end{array}$ \\
\hline $\begin{array}{l}\text { Shindelman, Ortmeyer, Sussman } \\
(1981)^{12}\end{array}$ & $\begin{array}{l}\text { Binding of }{ }^{125} \text { I-labelled transferrin to human } \\
\text { breast tumour cells in suspension }\end{array}$ & $\begin{array}{l}\text { TR present in human breast carcinoma ( } 10 \\
\text { cases) and breast sarcoma ( } 1 \text { case) }\end{array}$ \\
\hline Trowbridge, Omary $(1981)^{2}$ & $\begin{array}{l}\text { Purification from deoxycholate-solubilized } \\
\text { membranes by affinity chromatography on a } \\
\text { monoclonal antibody-Sepharose column }\end{array}$ & $\begin{array}{l}\text { TR present on cultured human T leukaemia } \\
\text { cell lines (RPMI 8402, CCRF-CEM, } \\
\text { HPB-ALL) }\end{array}$ \\
\hline Lebman et al. $(1982)^{13}$ & $\begin{array}{l}\text { Immunfluorescence of human cell lines using } \\
\text { monoclonal antibody L5.1 }\end{array}$ & $\begin{array}{l}\text { Human erythroid precursors, PHA } \\
\text { stimulated peripheral blood lymphocytes, } \\
\text { colorectal cancer and melanoma cell lines } \\
\text { positive. Mature blood cells, most leukaemia } \\
\text { and other epithelial cell lines all negative. }\end{array}$ \\
\hline
\end{tabular}

Table 2 Immunoperoxidase labelling of normal tissues with BK19.9. Monoclonal antibodies B3/25, T56/14 and T58/1 were studied on a selection of these tissues*

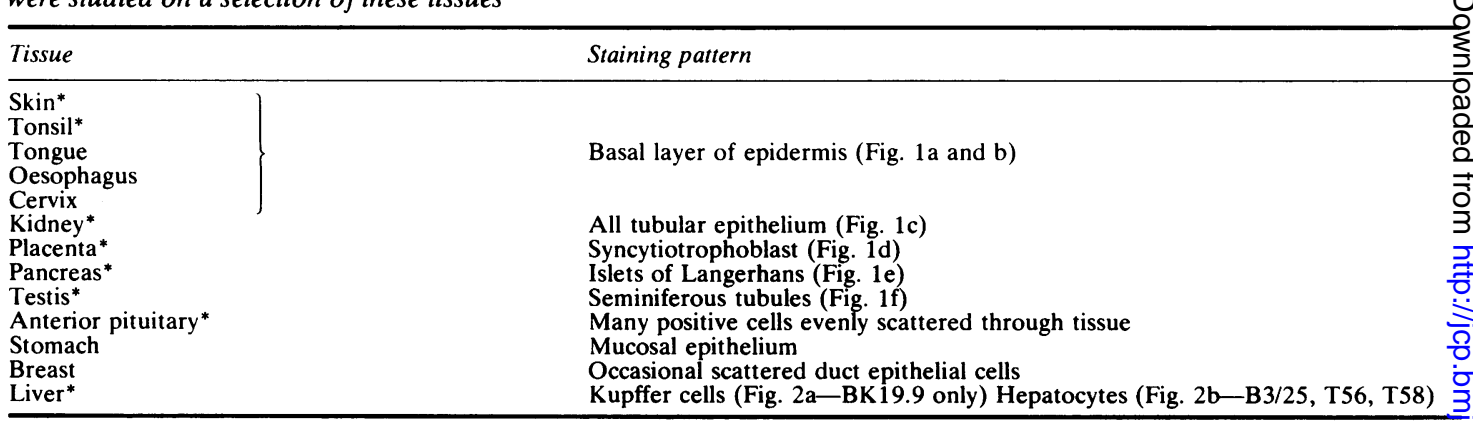

Tissues showing consistent negative staining: prostate, ovary, thyroid, lung, adrenal cortex, submandibular gland, synovium and colon. $\delta$ In lymphoid tissue scattered weakly stained cells were widely distributed with germinal centres showing diffuse weak labelling of variable intensity. In connective and inflammatory tissue scattered weakly stained cells, often with the morphological appearance of macrophages (including giant cells) were seen.

*Tissues tested with B3/25, T56/14, T58/1.4.

refrigerator. Cryostat sections $(5-10 \mu \mathrm{m}$ in thickness) were collected on gelatin-coated glass slides, thoroughly dried (by desiccation for 4-18 h in the vacuum chamber of a freeze drying apparatus) and fixed in acetone for $10 \mathrm{~min}$ at room temperature. Sections were then air-dried and either stained immediately by the immunoperoxidase procedure (see below) or else wrapped in aluminium foil and stored at $-20^{\circ} \mathrm{C}$.

\section{ANTIBODIES}

The production of the monoclonal antibody BK19.9, and the evidence for its specificity for human TR has been described previously. ${ }^{14}$ BK19. is of murine origin and was used for immunohisf tological staining as undiluted tissue culture superN natant. Three other anti-TR monoclonal antibodies also of murine origin (B3/25, T56/14, T58/1-alt from the Salk Institute) of which B3/25 has bee extensively characterised ${ }^{2} 1516$ were obtained as $I_{\mathscr{g}}^{\Phi}$ purified from ascitic fluid and used at appropriate dilutions in Tris-buffered saline.

A monoclonal antibody reactive with huma家 monocytes (OKM) was purchased from Orthe्के Pharmaceutical Corporation (Raritan, New Jerse f USA). 


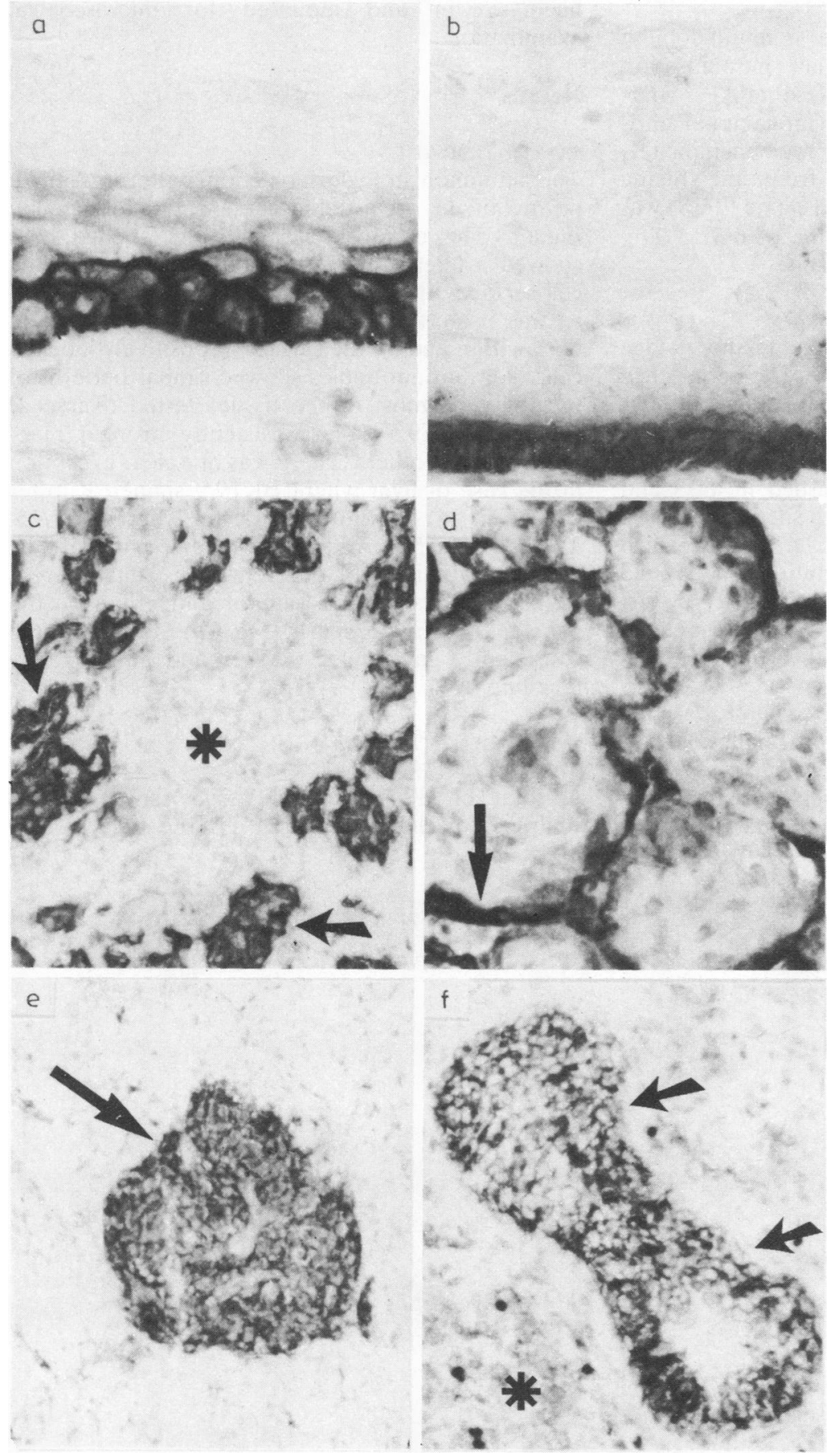

Fig. 1 Normal tissues labelled by the immunoperoxidase method with the monoclonal anti-transferrin receptor antibody BK19.9. (a) Normal skin showing labelling of the basal layer of the epidermis $\times 800$. (b) Labelling of the basal layer of normal non-keratinising epithelium in the ectocervix $\times 500$. (c) Positively labelled proximal renal tubules (arrow) in kidney contrasting with a negative glomerulus (asterisk) $\times 200$. (d) Positively labelled syncytiotrophoblast (arrow) contrasting with the negative central core of cytotrophoblast in the placenta $\times 800$. (e) Normal pancreas showing positive labelling of an islet of Langerhans (arrow) with surrounding negative exocrine pancreas $\times 200$. ( $f$ ) Positively labelled testicular tubule (arrows) surrounded by seminoma (*) which is more weakly stained $\times 200$. 


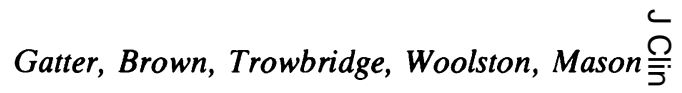

IMMUNOPEROXIDASE REAGENTS

Sheep antiserum against mouse immunoglobulin was raised by a conventional immunisation schedule. Peroxidase:antiperoxidase (PAP) complexes were prepared using the monoclonal antiperoxidase antibody $\mathrm{P} 6 / 38 .{ }^{17}$ Diaminobenzidine tetrahydrochloride was obtained from the Sigma Chemical Company. Tris-buffered saline (TBS) was prepared by adding a tenth volume of $0.5 \mathrm{M}$ Tris $\mathrm{HCl}$ buffer ( $\mathrm{pH} \mathrm{7.6)}$ to $0.15 \mathrm{M}$ saline.

\section{IMMUNOPEROXIDASE STAINING}

Cryostat sections were stained by the three-stage PAP immunoperoxidase procedure. The initial stage involved the application of 50-100 $\mu \mathrm{l}$ of antibodycontaining supernatant to dry cryostat sections, followed by incubation for $30 \mathrm{~min}$ in a covered chamber. Sections were then washed in TBS and incubated for a further $30 \mathrm{~min}$ with sheep antimouse Ig. This reagent was diluted $1 / 25$ in TBS to which normal human serum (at a final dilution of 1/25) had been added in order to block cross-reactivity against human Ig. After a further wash in TBS, monoclonal PAP was applied for $30 \mathrm{~min}$ with a final wash in TBS.

Development of the peroxidase reaction was performed by incubating sections with diaminobenzidine $(0.6 \mathrm{mg} / \mathrm{ml})$ and hydrogen peroxide $(0.01 \%)$ in TBS for 5-10 min at room temperature. Sections were then washed in tap water, counterstained with haematoxylin and mounted for microscopical@ examination.

\section{Results}

NORMAL TISSUES

The immunohistological reaction patterns seen in $\overline{\bar{s}}$ normal tissues are listed in Table 2 and illustrated in Fig. 1. The majority of positively labelled cells showed a linear reaction product demarcating the cell surface. In addition diffuse cytoplasmic positiv- $\overrightarrow{0}$ ity was also often seen suggesting that TR is present $\overrightarrow{-}$ both within and on the surface of positively labelledō cells. All four antibodies showed similar patterns otō reactivity on most of the tissues tested (Table 2) although BK19.9 gave consistently stronger reac-o tions than the others. There was one clear exceptione in the case of liver where BK19.9 stained Kupffere cells (Fig. 2a) and not hepatocytes whereas B3/25, T56/14 and T58/1.4 gave the reverse pattern (Fig. $2 b)$. The other major difference was that whereasz BK19.9 always stained islets of Langerhans in the pancreas extremely clearly (Fig. 1e) the other three consistently gave much weaker and more patchyọ labelling.

\section{MALIGNANT TISSUES}

Antibody BK19.9

A total of 87 neoplastic tissue samples were analysed for the presence of TR by staining with $\stackrel{\AA}{\circ}$
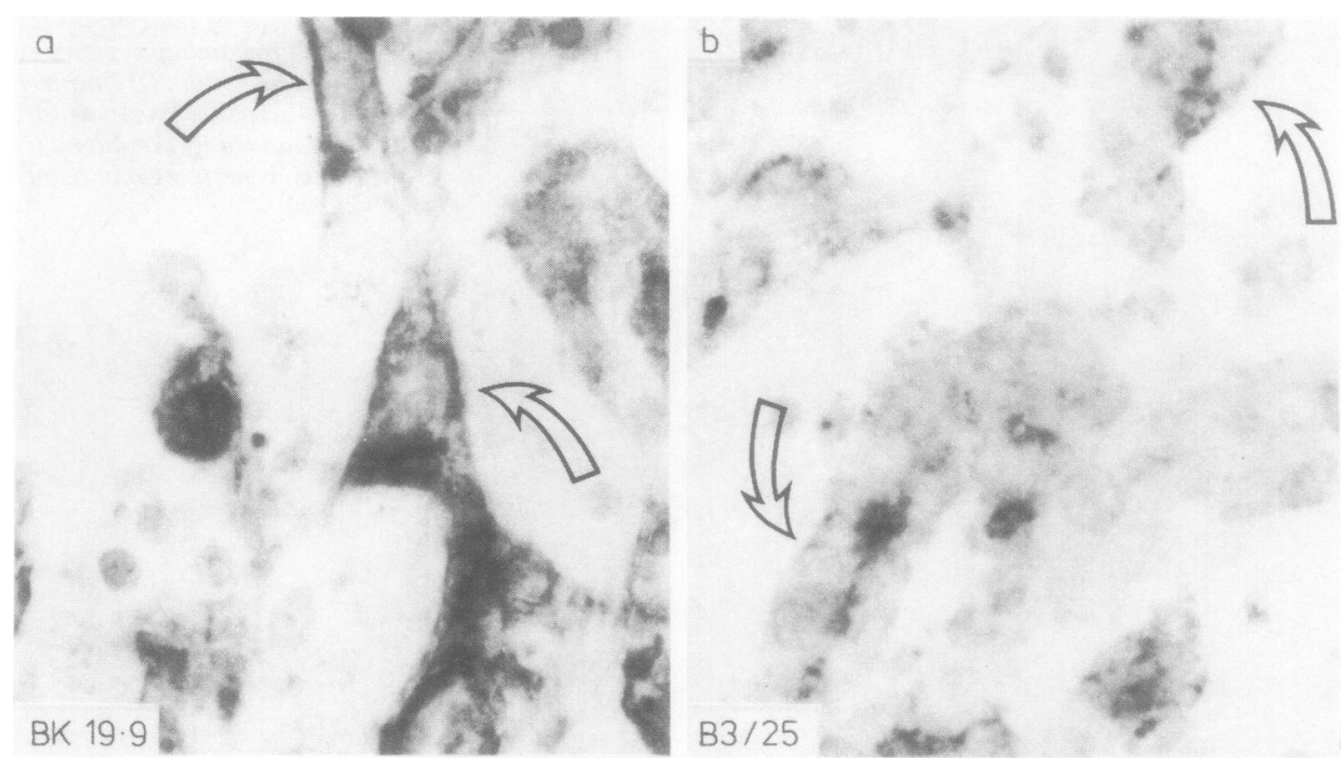

Fig. 2 (a) Kupffer cells (arrow) in liver, positively labelled by monoclonal antibody BK19.9, contrasting with negative hepatocytes $\times 800$. (b) Hepatocytes (arrow) positively labelled by monoclonal antibody B3/25, in an adjacent section from the same biopsy as illustrated in Fig. $2 a \times 800$. 
Table 3 Immunoperoxidase labelling of malignant tissue with the anti-transferrin receptor antibody BK19.9

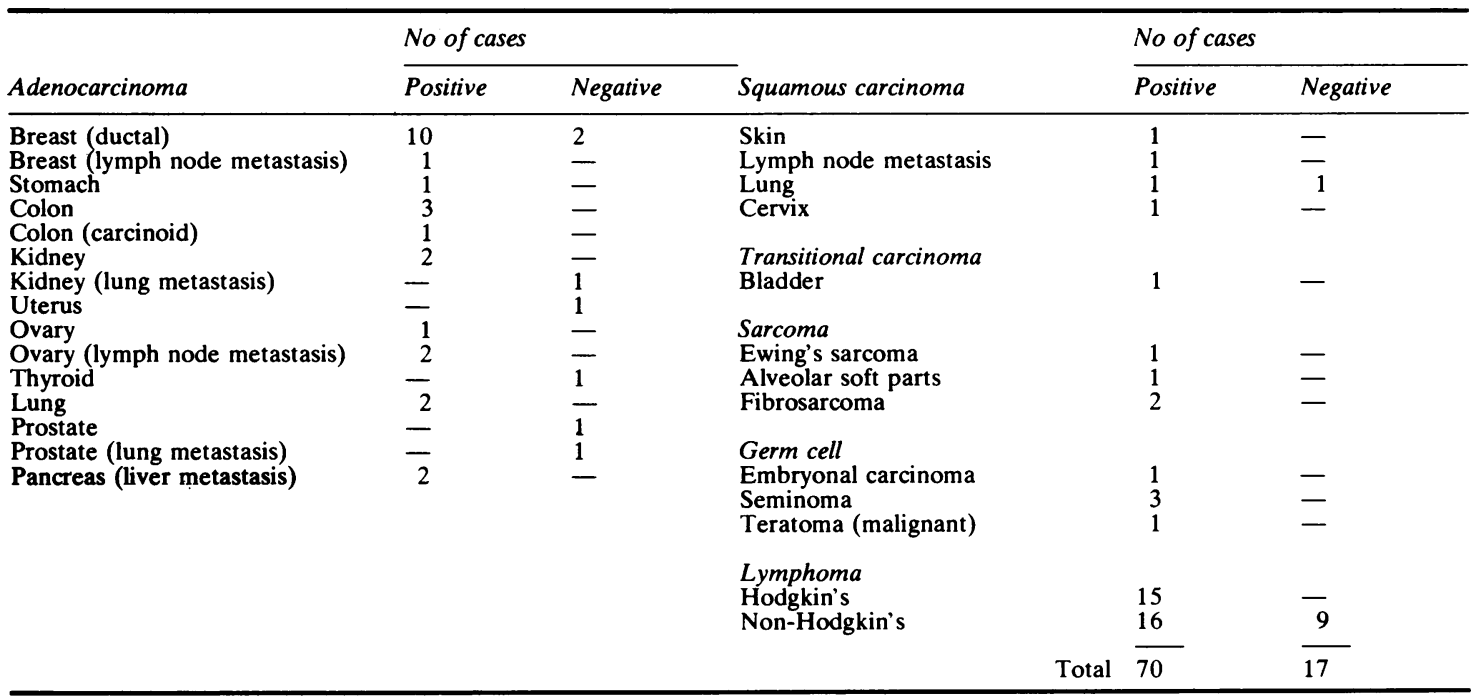

antibody BK19.9. As seen in Table 3 many of these cases gave positive staining reactions.

Carcinomas Staining was seen in $\mathbf{3 0}$ of the 38 cases with most samples showing a strong labelling reaction. The pattern of staining, however, varied; in some cases there was generalised diffuse labelling of all neoplastic cells (Fig. 3), whilst in other cases positively stained cells were present (as isolated scattered cells or in groups) against a background of unstained neoplastic cells.

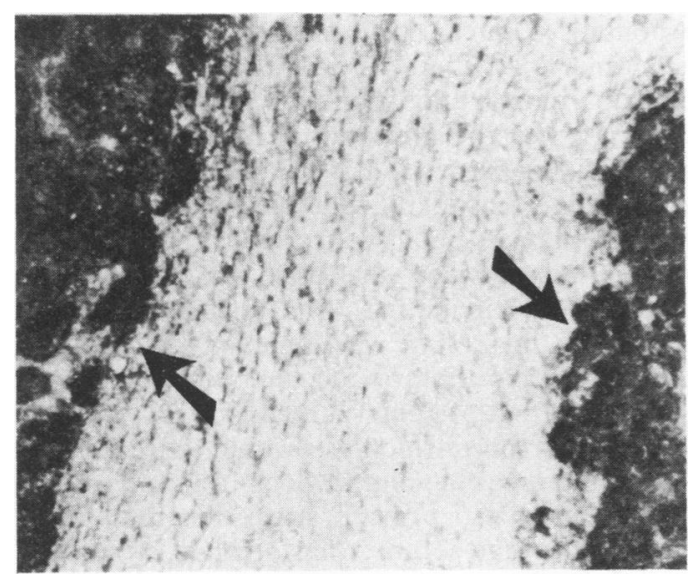

Fig. 3 Two nodules (arrowed) of secondary adenocarcinoma of the pancreas in liver showing strong positive labelling with the monoclonal antibody BK19.9. The positively labelled scattered cells in the liver (centre) are Kupffer cells $\times 200$.
Germ cell tumours and sarcomas All nine cases in this group of primitive tumours stained positively for TR.

Non-Hodgkin's lymphoma Among 25 cases, including both nodular and diffuse types of lymphoma, 16 samples showed staining, usually relatively weak, of the neoplastic cell population.

Hodgkin's disease All 15 cases of Hodgkin's disease examined showed weak staining of numerous cells in areas of active disease including obvious mononuclear Hodgkin and multinuclear Reed Sternberg cells. In addition, in cases of nodular sclerosing disease, the inflammatory infiltrate in the fibrous tissue bands contains scattered weakly staining cells, many with the morphological appearance of macrophages. Positive staining with the monoclonal anti-monocyte antibody OKM provided additional evidence for the phagocytic nature of these cells.

\section{Antibodies B3/25, T56/14 and T58/1}

$A$ small number of representative neoplastic biopsies were also stained with B3/25, T56/14 and T58/1. All three antibodies gave the same staining pattern, being generally weaker and more patchy than the staining with BK19.9.

\section{Discussion}

This study has shown that TR, as detected by four monoclonal antibodies shows a restricted expression pattern in normal human tissue. It is present in the 
basal layers of squamous epithelium (both keratinising and non-keratinising-Fig. 1), but not in more superficial cell layers. Furthermore it is found in the endocrine pancreas (but not the exocrine portion of the gland), in seminiferous tubules of the testis, in the pituitary, in Kupffer cells of the liver (Fig. 2aBK19.9 only) and hepatocytes (Fig. 2b-B3/25, T56/14 and T58/1). Macrophages in many tissues also appear to express TR.

The explanation of this pattern of TR distribution is not immediately apparent. Its selective presence in the basal layers of squamous epithelium is in keeping with reports that it is expressed on rapidly proliferating cells. ${ }^{23}$ This may also account for its expression on seminiferous tubules. At other sites, however-for example, endocrine pancreas-such an explanation is not tenable.

Whatever the underlying reasons for these patterns of TR expression it is striking that they show partial correlation with the sites (skin, pancreas, testis, pituitary, and liver) at which excessive iron deposition occurs in primary haemochromatosis. This suggests that tissues which sustain damage in this disease may be susceptible because of high levels of TR expression. It is not possible, however, solely on the basis of this immunohistological analysis, to assess whether this explanation of the pathogenesis of tissue damage in primary haemachromatosis is valid. It should be noted that at least two sites which are not generally recognised as being particularly susceptible to damage from excess iron deposition were clearly labelled with anti-TR (kidney and gut). A striking finding was that hepatocytes and Kupffer cells both of which are known to express $T^{18}$ gave different labelling patterns with BK19.9 compared to the other three monoclonal anti-TR antibodies (Fig. 2). The other major difference between BK19.9 and the other antibodies was that whereas BK19.9 stained islets of Langerhans strongly and completely (Fig. 1e) the others were consistently much weaker and patchier.

The explanation of the fact that four antibodies of apparently identical specificities, gave different immunohistological labelling patterns remains to be elucidated. This discrepancy could reflect the fact that the transferrin receptor is not a single molecular entity but rather a family of molecules which are antigenically similar but not identical. There is a precedent for this in the description ${ }^{19}$ of monoclonal antibodies which will distinguish sub-populations of the leucocyte-associated antigen. It is indeed possible that the striking molecular similarity between the transferrin receptor and the malignancy associated antigen ${ }^{5}$ (see Introduction) may also be explained by the fact that both belong to a family of structurally related but antigenically distinct molecules concerned with molecular binding and transportation-that is, transferrin and glucose respectively. The recently reported "family" of molecules represented by the macrophage antigen MAC-1 and the lymphoid antigen LFA-1 ${ }^{2021}$ provides a precedent in this context.

Finally TR was found to be present on the majority of carcinomas, on all sarcomas and on all cases of Hodgkin's disease examined. In contrast nonHodgkin's lymphomas were either weakly labelled or gave (in approximately one third of cases) a negative reaction.

These results should be interpreted in the context of previous studies in animals which have shown a relation between the rate of tumour proliferation, tumour mass and the uptake of transferrin by tumours. ${ }^{22}$ This suggests that a relation may exist between TR expression and the growth rate or differentiation of human tumours. This is supported by a recent study showing that anti-transferrin receptor antibody inhibited the growth of human melanoma cells in nude mice. ${ }^{23}$ However it should be noted that in the present study staining for transferrin receptor was not obviously related to tumour differentiation or mitotic rate, and indeed some secondary tumours were entirely negative for TR (Table 3 ).

One point of interest that is raised by TR expression in human tumours concerns the pathogenesis of the chronic anaemias which are often associated with advanced malignancy. Such anaemias can only rarely be shown to be due to bone marrow invasion and almost certainly have a multi-factorial aetiology. The major factors causing the anaemia are generally agreed to be increased haemolysis with an inadequate bone marrow erythropoietic response..$^{24}{ }^{25}$ Lamar et $a l^{26}$ have shown in rats with a hepatoma that there is an approximately $50 \%$ reduction in iron utilisation by bone marrow, with a concomitant rise in utilisation by the spleen. In view of the striking expression of TR in human malignant cells it seems reasonable that one causative factor in the anaemia associated with cancer could be direct competition between the bone marrow and the tumour for circulating transferrin-bound iron. Although Lamar et al $^{26}$ were unable to show any net increase in iron utilisation in tumour-bearing rats it is probable that the total amount of iron available for bone marrow normoblasts would decrease as the tumour increases in volume. Such iron utilisation by tumours may also provide an explanation for the observation that serum transferrin is significantly lower in patients with malignant disease. ${ }^{27}$

We thank the Wellcome Trust and the Leukaemia Research Fund for financial assistance and Miss Tina Chisnall for typing the manuscript. 


\section{References}

' Judd W, Poodry CA, Strominger JL. Novel surface antigen expressed on dividing cells but absent from non-dividing cells. $J$ Exp Med 1980;152:1430-5.

${ }^{2}$ Trowbridge IS, Omary MB. Human cell surface glycoprotein related to cell proliferation is the receptor for transferrin. Proc Natl Acad Sci USA 1981;78:3039-43.

${ }^{3}$ Sutherland R, Delia D, Schneider C, et al. Ubiquitous cellsurface glycoprotein on tumour cells is proliferation associated receptor for transferrin. Proc Natl Acad Sci USA 1981;78:4515-9.

${ }^{4}$ Hellstrom KE, Doolittle RF, Dreyer WJ, et al. Human melanoma-associated antigen p97 is structurally and functionally related to transferrin. Nature 1982;296:171-3.

${ }^{5}$ Bramwell ME, Harris $\mathrm{H}$. An abnormal membrance glycoprotein associated with malignancy in a wide range of different tumours. Proc $R$ Soc Lond B 1978;201:87-106.

${ }^{\circ}$ Larrick JW, Cresswell P. Transferrin receptors on human B and T lymphoblastoid cell lines. Biochim Biophys Acta 1979;583:483-90.

' Seligman PA, Schleicher RB, Allen RH. Isolation and characterization of the transferrin receptor from human placenta. J Biol Chem 1979;254:9943-6.

${ }^{8}$ Wada GH, Hass PE, Sussman HH. Transferrin receptor in human placental brush border membranes. J Biol Chem 1979;254:12629-35.

${ }^{9}$ Faulk WP, Hsi B-L, Stevens PJ. Transferrin and transferrin receptors in carcinoma of the breast. Lancet 1980;ii:390-2.

${ }^{10}$ Enns CA, Shindelman JE, Tonik SE, et al. Radioimmunochemical measurement of the transferrin receptor in human trophoblast and reticulocyte membranes with a specific anti-receptor antibody. Proc Natl Acad Sci USA 1981;78:4222-5.

" Goding JW, Burns GF. Monoclonal antibody OKT-9 recognizes the receptor for transferrin on human acute lymphocytic leukaemia cells. J Immunol 1981;127:1256-8.

${ }^{12}$ Shindelman JE, Ortmeyer AE, Sussman HH. Demonstration of the transfe-rin receptor in human breast cancer tissue. Potential marker for identifying dividing cells. Int $J$ Cancer 1981;44:1301-10.

${ }^{13}$ Lebman D, Trucco M, Bottero L, et al. A monclonal antibody that detects expression of transferrin receptor in human erythroid precursor cells. Blood 1982;59:671-8.

${ }^{14}$ Brown G, Kourilsky FM, Fisher AG, et al. Strategy for screening for monoclonal antibodies against cellular antigens expressed on minor cell populations or in low amounts. Human Lymph Differentiation 1981;1:167-82. is Omary MB, Trowbridge IS, Minowada J. Human cell-surface glycoprotein with unusual properties. Nature 1980;286:88891.

${ }^{16}$ Omary MB, Trowbridge IS. Biosynthesis of the human transferrin receptor in cultured cells. J Biol Chem 1981;256:1288892.

${ }^{17}$ Mason DY, Cordell JL, Abdulaziz Z, et al. Preparation of PAP complexes for immunohistological labelling of monoclonal antibodies. J Histochem Cytochem 1982;30:1114-22.

18 Young SP, Aisen P. The interaction of transferrin with isolated hepatocytes. Biochim Biophys Acta 1980;633:145-53.

19 Dalchau R, Fabre JW. Identification with a monoclonal antibody of a predominantly B lymphocyte-specific determinant of the human leucocyte common antigen. $J$ Exp Med 1981;153:753-65.

${ }^{20}$ Trowbridge IS, Omary MB. Molecular complexity of leukocyte surface glycoproteins related to the macrophage differentiation antigen Mac-l. J Exp Med 1981;1517-24.

${ }^{21}$ Kurzinger M, May-Kin HO, Springer TA. Structural homology of a macrophage differentiation antigen and an antigen involved in T-cell-mediated killing. Nature 1982;296:668-70.

${ }^{22}$ Aulbert E, Disselhoff W, Sorje H, Schulz E, Gericke D. Lysosomal accumulation of ${ }^{\circ} \mathrm{Ga}$-Transferrin in malignant tumours in relation to their growth rate. Eur $J$ Cancer 1980;16:1217-32.

${ }^{23}$ Trowbridge IS, Domingo DL. Anti-transferrin receptor monoclonal antibody and toxin-antibody conjugates affect growth of human tumour cells. Nature 1981;294:171-3.

${ }^{24}$ Hyman GA, Harvey JE. The pathogenesis of anaemia in patients with carcinoma. Am J Med 1955;19:350-6.

${ }^{25}$ Degowin RL, Grund FM, Gibson DP. Erythropoietic insufficiency in mice with extramedullary tumour. Blood 1978;51:33-43.

${ }^{26}$ Lamar C, Greene AS, Greene WB. Host-tumour interactions: basis for the anaemia in rats bearing the hepatoma 7777. Am J Hematol 1979;7:127-35.

${ }^{27}$ Hughes NR. Serum transferrin and ceruloplasmin concentrations in patients with carcinoma, melanoma, sarcoma and cancers of haematopoietic tissues. Aust J Exp Biol Med Sci 1972;50:97107.

Requests for reprints to: Dr KC Gatter, Nuffield Department of Pathology, University of Oxford, John Radcliffe Hospital, Oxford, England. 